\title{
Pemulihan Aset Wakaf: Tinjauan Fikih dan Akuntansi
}

\author{
Ifa Hanifia Senjiati \\ Muamalah, Fakultas Syariah, Universitas Islam Bandung \\ ifa.wahyudin@gmail.com
}

\section{Siska Lis Sulistiani}

Akhwal Syakhsiyah, Fakultas Syariah, Universitas Islam Bandung siscaassidq@yahoo.co.id

\section{Itsnaina Lathifah Ridwan}

Muamalah, Fakultas Syariah, Universitas Islam Bandung itsnainalathifahr97@gmail.com

\begin{abstract}
Wakaf Daarut Tauhid manages waqf in the form of a vehicle. Vehicles are waqf assets that are easily impaired so depreciation is necessary. However, in practice, the waqf Daarut Tauhid does not make accounting records for the depreciation of the assets of the vehicle's waqf. Therefore, this study aims to analyze ways of recovering waqf assets that have been depreciated using waqf review and accounting. The research method used is qualitative with a descriptive analysis approach. Data collection techniques through interviews and literature study. The results of the study are several steps to recover waqf assets in waqf institutions by revaluating the waqf assets received, and determine the economic age, depreciation costs, and the appropriate depreciation method to be used. Making a plan for recovering waqf assets with taghyir al-waqf, or Istibdlal and recording these transactions in the financial statements based on PSAK 48 paragraph 01.
\end{abstract}

Keywords: asset recovery, depreciation, waqf, accounting, istibdal

\begin{abstract}
Abstrak
Wakaf Daarut Tauhid mengelola wakaf bergerak berupa kendaraan. Kendaraan merupakan aset wakaf yang mudah mengalami penurunan nilai sehingga perlu dilakukan penyusutan. Namun, dalam prakteknya wakaf Daarut Tauhid tidak melakukan pencatatan akuntansi atas penyusutan aset wakaf kendaraan tersebut. Oleh karena itu, penelitian ini mempunyai tujuan untuk menganalisis cara pemulihan aset wakaf yang mengalami penurunan nilai menggunakan tinjauan fikih wakaf dan akuntansi. Metode penelitian yang digunakan kualitatif dengan pendekatan deskriptif analisis. Teknik pengumpulan data melalui wawancara dan studi kepustakaan. Hasil penelitian adalah beberapa langkah untuk melakukan pemulihan aset wakaf pada lembaga wakaf dengan cara melakukan revaluasi aset wakaf yang diterima, dan menentukan umur ekonomis, biaya penyusutan serta metode penyusutan yang tepat untuk digunakan. Membuat perencanaan pemulihan aset wakaf dengan taghyir alwaqf, atau Istibdlal serta melakukan pencatatan atas transaksi tersebut dalam laporan keuangan berdasarkan PSAK 48 paragraf 01.
\end{abstract}

Kata Kunci: pemulihan aset, penyusutan, wakaf, akuntansi, istibdal 


\section{Pendahuluan}

Menurut undang-undang nomor 41 Tahun 2004 aset wakaf disebut harta benda wakaf yaitu harta benda wakaf yang memiliki daya tahan lama dan/atau manfaat jangka panjang serta mempunyai nilai ekonomi menurut syariah yang diwakafkan oleh wakif (Presiden Republik Indonesia, 2004). Kebanyakan dari aset wakaf yang dikelola lembaga wakaf adalah berupa aset tetap seperti tanah dan bangunan yang diperuntukkan untuk masjid, madrasah, pemakaman (Arief \& Tulab, 2018). Bentuk aset wakaf lainnya seperti wakaf saham yang telah dilakukan oleh Bursa Efek Indonesia atas kerja sama dengan BNI sekuritas dan Yayasan Aksi Cepat Tanggap (Suryowati, 2019).

Jenis aset wakaf yang beragam seharusnya dapat disajikan dalam laporan keuangan. Ketika Lembaga wakaf menerima aset berupa kendaraan maka kendaraan tersebut harus dicatat sesuai nilai wajar pada saat penerimaan aset wakaf dan disajikan dalam laporan keuangan. Namun, dalam faktanya penerimaan aset wakaf berupa kendaraan tidak dinilai, dicatat dan disajikan dalam laporan keuangan (Hakim, 2019). Aset wakaf berupa aset tetap baik bergerak atau tidak bergerak akan mengalami penurunan nilai. Padahal, aset wakaf semestinya tidak boleh hilang asetnya atau manfaatnya. Sehingga penurunan nilai aset wakaf perlu dilakukan pengakuan dan pengukurannya yang dilindungi oleh aturan pemerintah dan undang-undang (Nasar, 2018) agar terhindar dari kemungkinan penyalahgunaan aset wakaf oleh siapa pun (Fawzi, 2011) (Bimas Islam, 2013). Aspek keamanan dalam wakaf yaitu terjaminnya keamanan nilai pokok dana abadi sehingga tidak terjadi penyusutan (jaminan keutuhan) (Santoso, 2017) (Kasdi, 2014). Menurut PSAK 112, aset wakaf yang dapat disusutkan adalah kendaraan dan bangunan (SINDO, 2018). Aset wakaf permanen berupa depreciable assets dapat disusutkan, diturunkan nilainya ketika terjadi penurunan nilai (impairment), atau diukur ulang (remeasurement). Keabadian dari aset wakaf permanen melekat pada keberadaan zatnya (Dewan Standar Akuntansi Syariah IAI, 2018).

Faktor yang menyebabkan penurunan manfaat aktiva tetap antara lain, penyusutan fisik, penyusutan fungsional, di mana suatu aktiva mengalami ketidaklayakan (inadequacy) dan ketinggalan zaman (obsolescerce). Untuk mencapai kelanggengan manfaat dan ain wakaf dibutuhkan biaya untuk menutupi beban pemeliharaan yang telah dikeluarkan. Pendapatan inilah yang menjadi kajian studi kelayakan ekonomi suatu proyek harta wakaf (Huda \& Heykal, 2015).

Contoh penurunan nilai aset wakaf terjadi pada (1) proses ruislag tanah dan bangunan wakaf, nilai harta penukar tidak boleh mengalami penyusutan kuantitas maupun manfaat 
(Nasar, Nazhir Wajib Pahami Hukum Wakaf, 2018). (2) penurunan nilai atas wakaf uang. uang berpotensi mengalami penurunan nilai karena inflasi sebab negara Indonesia menganut sistem moneter fiat standard, bukan commodity standard. Oleh karena itu, nadzir perlu memperhatikan hal ini melalui pengembangan uang wakaf dengan cara investasi, tapi memiliki standar yang jelas dalam akuntansinya (Hasanah, 2009). (3) penurunan nilai pada wakaf saham, Badan Wakaf Indonesia (BWI) menilai perlu peraturan wakaf saham terkait dengan mitigasi risiko dari penurunan nilai. Pasalnya, saham yang menjadi harta wakaf sangat rentan mengalami fluktuasi nilai (Saptono, 2019).

Berdasarkan uraian di atas, maka perlu dilakukan pemulihan aset dengan melakukan sistem akuntansi atas penyusutan aset wakaf karena wakaf merupakan instrumen penting dalam sistem ekonomi masyarakat Muslim yang sangat diharapkan dapat membantu meningkatkan taraf hidup mereka menjadi lebih baik (Bayinah, 2017). Salah satu lembaga wakaf yang memiliki aset wakaf bergerak dan tidak bergerak adalah Wakaf Daarut Tauhiid. Dan pembahasan akan fokus pada aset wakaf bergerak berupa kendaraan karena kendaraan merupakan aset yang sangat mudah mengalami penurunan nilai (Fahruroji, 2017). Penurunan aset wakaf yang terjadi di Wakaf Daarut Tauhid tidak dilakukan pengakuan, pengukuran dan penyajian pada laporan keuangan. Aset wakaf berupa kendaraan yang diterima Wakaf Daarut Tauhid pada bulan November 2018 berupa mobil Carry tahun 2001(wakaf daarut Tauhid, 2018) tidak dicatat, tidak diakui dan tidak disajikan dalam laporan keuangan (Hakim, 2019).

Berdasarkan latar belakang di atas maka rumusan masalah penelitian ini adalah (1) bagaimana tinjauan fikih dan akuntansi wakaf terkait pemulihan aset wakaf? dan (2) bagaimana pemulihan aset wakaf pada lembaga wakaf? tujuan penelitian ini adalah (1) untuk mengetahui tinjauan fikih dan akuntansi wakaf terkait pemulihan aset wakaf. (2) untuk mengetahui pemulihan aset wakaf pada lembaga wakaf.

Secara teori wakaf adalah bentuk donasi yang diberikan seseorang dengan bersifat sukarela dengan dana atau pokok wakafnya tetap terjaga dan terpelihara. Hal ini berdasarkan penggalan Hadis Rasulullah Saw, beliau bersabda : “....... Bila engkau suka, kau tahan (pokoknya) tanah itu, dan engkau sedekahkan (hasilnya)...... “. Makna atas hadis ini dipahami oleh beberapa imam dan alim ulama adalah menitikberatkan kepada pemanfaatan aset wakaf, sedangkan kepemilikan, boleh masih dimiliki oleh wakif, atau wakif memberikan penuh kepemilikan dan dikelola oleh nadzir (kementrian Agama, 2006). Dengan demikian, maka apabila aset wakaf diartikan sebagai aset yang manfaatnya harus tetap ada dan terjaga 
maka menjaga nilai aset wakaf perlu dilakukan salah satunya adalah dengan melakukan pemulihan aset wakaf.

\section{Metode Penelitian}

Metode penelitian yang digunakan dalam penelitian ini adalah metode penelitian kualitatif dengan deskriptif analisis. Metode kualitatif adalah jenis penelitian yang temuantemuannya tidak diperoleh melalui prosedur statistik atau bentuk hitungan lainnya (Strauss dan Corbi, 2003 dalam Afrizal) (Afrizal, 2016). Pendekatan penelitian yang digunakan adalah studi kasus. Studi kasus dalam penelitian ini adalah pada Lembaga Wakaf Yayasan Daarut Tauhid atau biasa disebut Wakaf DT. Pemilihan objek penelitian ini karena Wakaf DT memiliki produk aset wakaf tetap dan tidak tetap seperti kendaraan, sehingga pemilihan objek dirasakan tepat mengingat aset tidak tetap sangat cepat mengalami penurunan aset.

Sumber data yang digunakan pada penelitian ini adalah menggunakan data primer dan data sekunder. Data primer adalah data yang diperoleh secara langsung, baik berupa wawancara kepada staf accounting Wakaf Daarut Tauhid, dan observasi langsung ke lapangan. Selain itu, menggunakan bahan hukum primer berupa aturan pada Pernyataan Standar Akuntansi Keuangan (PSAK) yang ditetapkan oleh Ikatan Akuntan Indonesia.

Teknik analisis data dalam penelitian ini adalah menggunakan deskriptif analisis yaitu uraian apa adanya terhadap suatu kondisi, dengan cara evaluatif yaitu melakukan penilaian atau mengevaluasi tepat atau tidak tepat, benar atau tidak benar, dan sah atau tidak sah suatu pandangan, proposisi, pernyataan rumusan, atau keputusan. Agar data miliki nilai validitas dalam penelitian, maka peneliti melakukan teknik triangulasi (Afrizal, 2016). Validitas data dalam penalian ini adalah melakukan konfirmasi dan klarifikasi data yang diperoleh dari pihak wakaf Daarut Tauhid dan membandingkannya dengan data dari laporan keuangan. Selanjutnya, agar penelitian ini dapat diterima dan dipahami oleh pembaca maka pemilihan sampel penelitian dilakukan prosedur purposive sampling pada Lembaga wakaf Daarut Tauhid karena wakaf DT memiliki aset wakaf kendaraan dan tidak dilakukan pencatatan, pengakuan dan penyajian dalam laporan keuangan. Adapun untuk menguji reliabilitas/dependabilitas penelitian ini adalah dengan melakukan wawancara ulang dengan staf accounting pada waktu yang berbeda, sehingga diperoleh hasil yang sama dengan wawancara sebelumnya. 


\section{Hasil dan Pembahasan}

\section{Tinjauan Fikih dan Akuntansi Terhadap Pemulihan Aset Wakaf}

Fikih wakaf menurut pada fuqaha adalah menahan harta dan menyedekahkan manfaatnya untuk kebaikan agar dapat mendekatkan diri pada Allah SWT. Syarat wakaf menurut pendapat para ahli dalam PSAK NO.112 adalah tidak boleh ada perubahan atas nilainya. Selain itu menurut kalangan Hanafiyyah syarat bolehnya wakaf adalah keabadian. Maksud dari perubahan nilai tersebut adalah jika suatu aset nilainya semakin berkurang maka kualitas aset semakin berkurang sehingga menyebabkan aset kurang memberikan manfaat atau dapat menghilangkan keabadian aset. Selain itu, keabadian aset di sini bukan barangnya harus selalu tetap ada dan tidak boleh ada perubahan, namun maksudnya pengelolaan wakaf harus memberikan manfaat secara terus menerus. Aset wakaf memang diharapkan untuk memberikan manfaatnya secara terus menerus, namun tidak menutup kemungkinan bahwa di dunia ini tidak ada yang abadi sebagaimana aset wakaf, pasti akan mengalami kerusakan dikemudian hari. Rusaknya aset wakaf atau sudah tidak dapat dimanfaatkan lagi merupakan hal yang pasti terjadi, aset wakaf juga akan menemui masa kerusakannya. Mengetahui hal ini para fuqaha telah menentukan langkah yang harus diambil saat aset wakaf sudah mulai rusak.

Pengelolaan wakaf berdasarkan tinjauan fikih dalam melakukan pemulihan aset wakaf akibat dari penurunan nilai aset wakaf baik penyusutan atau amortisasi, sebagai berikut :

\section{Taghyir al-Waqf}

Taghyir al-waqf adalah perubahan terhadap tatanan wakaf. Tatanan wakaf yang masuk dalam term ini meliputi penerima alokasi manfaat, kadar manfaat yang diberikan, fisik atau bentuk aset, sarat wakif, dll. (M.Habibi, 2017). Menurut Hanafiah taghyir al-waqf ini tidak diperbolehkan terkecuali ada perubahan syarat dari wakif. Sedangkan Malikiyah boleh dilakukan taghyir al-waqf jika perubahannya kepada yang lebih baik dan wakaf bisa lebih tinggi lagi produktivitasnya. Teori ini didukung pernyataan al-Dasuqi : "boleh merubah sebagian tempat jika berdasarkan maslahat. Seperti merubah tempat berwudu dan dipindah ke lokasi lain dalam satu area”. Menurut Syafi'iyyah taghyir al-waqf adalah tindakan ilegal sebab menyalahi ketetapan-ketetapan yang bersumber dari wakif. Namun hal ini boleh dilakukan jika wakif mensyaratkan boleh dilakukan apa pun yang dipandang bermashlahat kepada wakaf. Sedangkan menurut Hanabilah boleh dilakukan jika menuju pada hal yang lebih maslahat (M.Habibi, 2017). 


\section{Istibdal al-waqf}

Wakaf dimaksudkan untuk pemanfaatannya selamanya, mendapatkan pahala dan ganjaran dengan manfaat dari barang itu. Muhammad Ibnul Hasan, mengatakan jika wakaf rusak dan tidak ada hasil dari wakaf yang bisa digunakan memperbaikinya, barang itu kembali kepada orang yang membangun atau ahli warisnya (Az-Zuhaili, 2011). Namun para fuqaha membolehkan mengganti barang wakaf, menjualnya karena darurat dengan syarat dan batasan tertentu. Berikut syarat penggantian harta wakaf(Az-Zuhaili, 2011):

1) Barang yang diwakafkan tidak bisa dimanfaatkan sama sekali

2) Tidak ada hasil wakaf yang bisa digunakan untuk memperbaiknya.

3) Penjualan aset wakaf tidak dengan penipuan yang keji.

4) Hendaklah orang yang mengganti adalah hakim yang saleh.

5) Yang diganti adalah pekarangan, bukan dirham dan dinar, supaya tidak dimakan oleh para pengawas.

6) Hendaklah hakim tidak menjualnya kepada orang yang tidak diterima kesaksiannya, tidak pula orang yang sedang mempunyai utang.

Berikut penyajian dalam bentuk tabel pandangan para fuqaha terkait pemulihan aset wakaf:

\begin{tabular}{|c|c|c|}
\hline & Taghyir Al-waqf & Istibdlal \\
\hline Hanafiyah & $\begin{array}{l}\text { Legalitas terbagi menjadi dua kondisi. } \\
\text { Pertama, berdasarkan maslahat. Kedua, } \\
\text { tidak ada maslahat. Hal ini boleh } \\
\text { dilakukan berdasarkan ketentuan dari } \\
\text { wakif atau jika ada maslahat yang } \\
\text { menuntut perubahan syarat. }\end{array}$ & $\begin{array}{l}\text { Memperbolehkan dengan syarat harta wakaf } \\
\text { sudah tidak bisa dimanfaatkan secara total, } \\
\text { tidak ada pendapatan dari harta wakaf yang } \\
\text { digunakan untuk merenovasi dan penjualan } \\
\text { tidak menyebabkan kerugian besar pada } \\
\text { wakaf. }\end{array}$ \\
\hline Malikiyah & $\begin{array}{l}\text { Boleh dilakukan jika terdapat msalahat } \\
\text { dan mendatangkan perubahan yang } \\
\text { produktivitasnya lebih baik. }\end{array}$ & $\begin{array}{l}\text { Jumhur Malikiyah menyatakan legalnya } \\
\text { istibdlal dan hanya berlaku untuk benda } \\
\text { bergerak dengan syarat ada maslahat. }\end{array}$ \\
\hline Syafïiyah & $\begin{array}{l}\text { Tindakan tersebut ilegal. Namun boleh } \\
\text { dilakukan jika waqif menyaratkan } \\
\text { dilakukannya apa pun jika lebih } \\
\text { memberikan manfaat. Dengan syarat: } \\
\text { Perubahan yang minimalis, tidak } \\
\text { menghilangkan bagian-bagiannya dan } \\
\text { berdasarkan maslahat dan tidak } \\
\text { membahayakan terhadap wakaf. }\end{array}$ & $\begin{array}{l}\text { Aset wakaf yang sudah tidak bermanfaat } \\
\text { berubah statusnya menjadi milik mauquf alaih } \\
\text { yang boleh ditasarrufkan, kecuali dengan } \\
\text { dijual atau dihibahkan. }\end{array}$ \\
\hline Hanabilah & $\begin{array}{l}\text { Terbagi menjadi dua sisi yaitu } \\
\text { perubahan arah alokasi manfaat dan } \\
\text { merubah bentuk mauquf. Dan kedua hal } \\
\text { tersebut diperbolehkan jika } \\
\text { mendatangkan maslahat. }\end{array}$ & $\begin{array}{l}\text { Terdapat dua pendapat. Pertama, tidak boleh } \\
\text { dilakukan kecuali dalam keadaan darurat atau } \\
\text { kondisi sudah tidak bermanfaat. Kedua, boleh } \\
\text { meskipun hanya karena maslahat yang lebih } \\
\text { unggul. }\end{array}$ \\
\hline
\end{tabular}

Tabel 1. Pengolahan Data tentang Pandangan Fuqoha terkait Pemulihan Aset Wakaf 
Taghyir al-waqf dapat dilakukan untuk aset wakaf yang berupa bangunan atau tanah. Contohnya jika ada bangunan yang diwakafkan dan kemudian pada awalnya untuk tempat operasional wakaf, namun karena banyaknya masyarakat sekitar yang pengangguran sehingga sebagian bangunan dibuka untuk tempat usaha bagi masyarakat. Selain itu dapat merubah dari sawah wakaf menjadi perkebunan. Perubahan atas pengelolaan aset wakaf dilakukan atas persetujuan wakif (Zaki, 2006).

Istibdlal dapat diterapkan adalah cocok untuk mesin atau kendaraan, karena mesin dan kendaraan cepat mengalami penurunan nilai maka jika aset tersebut sudah rusak dan kiranya sudah kurang memberikan manfaat yang layak maka aset dapat dijual dan membeli aset baru yang serupa fungsinya. Hal ini sejalan dengan hasil penelitian Ilyas yang menyatakan bahwa istibdal merupakan solusi akhir bagi aset wakaf yang sudah usang, tidak memberikan manfaat dan tidak memiliki daya guna. Istibdal dilakukan untuk menjaga kelestarian aset wakaf dan memberikan kemaslahatan kepada umat (Ilyas, 2016). Namun, menurut pendapat Imam al-Nawawi benda wakaf berupa masjid dilarang untuk dijual walaupun dalam kondisi rusak masih bisa digunakan untuk shalat, apabila akan ditukar dengan yang lebih maslahat maka diperbolehkan (Maftuhah, 2017). Bahkan pemerintah boleh melakukan ambil alih atas pelaksanaan istibdal, jika dirasa pengelola atau nadzir tidak mengelola dengan baik aset wakaf yang ada (Rani, 2015).

Selain dari fikih wakaf, pemulihan nilai pada aset wakaf dapat dilihat dari sisi akuntansi. Akuntansi wakaf terdiri dari dua kata, yakni akuntansi dan wakaf. Akuntansi secara bahasa diambil dari Bahasa Inggris yaitu accounting yang berarti menghitung, menimbang, mengalkulasikan, dll. Sementara wakaf secara bahasa diambil dari Bahasa Arab yang berasal dari kata waqafa-yaqifu-waqfan yang mana artinya semakna dengan kata habasa-yahbisu-tahbisan yakni terhalang untuk menggunakan. Sementara akuntansi dalam perspektif Islam adalah berhubungan dengan pengakuan, pengukuran dan pencatatan transaksi, serta pengungkapan hak-hak dan kewajiban-kewajibannya secara adil, sebagaimana firman Allah SWT dalam surat Al-Baqarah [2] ayat 282. Akuntansi dalam Islam harus fokus pada pelaporan yang jujur terkait posisi keuangan entitas dan hasil-hasil operasinya dengan mengungkapkan apa yang halal dan haram (Senjiati \& Sulistiani, 2019).

Akuntansi wakaf merupakan sistem yang mengatur pencatatan dan pelaporan pada wakaf. Hal ini diperlukan untuk pemeliharaan pada aset wakaf dan meningkatkan akuntabilitas pada lembaga wakaf. Peraturan untuk akuntansi wakaf ini mengacu pada PSAK No.112 tentang Akuntansi Wakaf. Selain itu, PSAK yang berkaitan dengan akuntansi 
wakaf adalah PSAK No.13 tentang Properti Investasi, PSAK No.16 tentang aset tetap, PSAK No.19 tentang Aset Tak Berwujud, PSAK No.110 tentang Akuntansi Sukuk serta PSAK No.71 tentang Instrumen Keuangan. PSAK yang mengatur terkait akuntansi wakaf ini bertujuan untuk meningkatkan transparansi dan akuntabilitas lembaga wakaf. selain itu, dengan adanya akuntansi wakaf ini dapat menghindari penyimpangan dan dapat mengontrol aset wakaf tersendiri agar tetap bermanfaat dan terakomodir.

Aset wakaf berupa benda bergerak yang mana memiliki risiko mudah mengalami penurunan nilai yang mengakibatkan berkurangnya manfaatnya yang diperoleh. dari sisi akuntansi termasuk ke dalam salah satu aset tetap yang dapat disusutkan karena mengalami penurunan nilai. Menurut PSAK No.48 pada paragraf 01 bahwa penurunan nilai yang dimaksud adalah jumlah tercatat melebihi jumlah terpulihkan, atau di mana masa ekonomis aset sudah habis dan sudah tidak bisa memberikan manfaat secara maksimal. Pada bagian paragraf 01 dijelaskan bahwa suatu aset yang mengalami penurunan haruslah dipulihkan melalui penggunaan atau penjualan aset (Ikatan Akuntan Indonesia, 2009). Maksud dijual adalah menjual barang yang mengalami penurunan nilai dan membelikan barang yang baru, agar nilai barang tetap sama. akuntansi mengatur penyusutan aset, sehingga ketika harga barang dijual lebih rendah dibanding harga beli maka dapat membeli aset yang setara, dengan tambahan dana dari beban penyusutan. Sedangkan maksud penggunaan adalah ketika mengalami penurunan nilai maka aset tersebut harus diperbaiki atau renovasi, untuk menambah harga peroleh di laporan keuangan. Sehingga aset dapat dioperasikan dengan baik. sebagai contoh bangunan yang dapat digunakan untuk produktif yang menghasilkan keuntungan.

Menurut PSAK 16: Aset Tetap paragraf 43 menyatakan bahwa setiap aset tetap yang memiliki biaya perolehan yang cukup signifikan terhadap total biaya perolehan, seluruh aset tetap disusutkan secara terpisah (Ikatan Akuntan Indonesia, 2015). Sedangkan dalam PSAK 19: Aset Tak Berwujud dan PSAK 110: Akuntansi Sukuk menyatakan bahwa jika aset mengalami penurunan nilai perlu diamortisasi. Sehingga akan muncul beban amortisasi dan diakui pada laporan laba rugi. Sementara aset wakaf yang termasuk properti investasi menerapkan pengaturan dalam PSAK 13: Properti Investasi termasuk penyusutannya. Beban penyusutan atau amortisasi dari aset wakaf merupakan bagian dari beban penyaluran manfaat wakaf kepada mauquf alaih.

Suatu aset wakaf yang mengalami penurunan nilai harus dipulihkan dan jika aset wakaf itu dapat disusutkan maka harus disusutkan, agar meminimalisir kerugian. Kerugian 
yang dapat dilihat dari penurunan nilai aset karena tidak dipulihkan adalah semakin lama, aset akan semakin rusak dan kas semakin berkurang karena harus mengeluarkan biaya operasional aset. Selain itu aset sudah tidak dapat dimanfaatkan kembali sehingga operasional bisa terhambat.

Berdasarkan dasar kesimpulan PSAK No.112 nomor 22 aset yang mengalami penurunan nilai akan disusutkan atau diamortisasi sesuai dengan jenis dan peruntukkan aset wakaf serta perlakuan akuntansi yang lazim untuk aset yang sejenis. Walaupun dikatakan aset wakaf tidak boleh ada perubahan atas nilainya namun, secara alamiah aset wakaf mengalami penurunan nilai. Sehingga ketika aset sudah benar-benar tidak dapat memberikan manfaat maka dapat membantu dalam pemeliharaan atau mengganti atau menambah aset yang sudah dimiliki. Dengan demikian, penyusutan atau pemulihan aset wakaf secara akuntansi adalah demi memberikan manfaat secara terus menerus, dan hal ini selaras dengan syarat wakaf yaitu memberikan manfaat yang abadi.

Pengakuan aset wakaf dapat dilihat dari beberapa Pernyataan Standar Akuntansi Keuangan (PSAK) nomor 112, 13, 16, 19 dan 110 yang berkaitan dengan aset wakaf, sebagai berikut:

\begin{tabular}{|c|c|c|}
\hline No & PSAK & Pengakuan \\
\hline 1 & $\begin{array}{l}\text { PSAK No.112 } \\
\text { tentang Akuntansi } \\
\text { Wakaf (IAI D. } \\
\text { Standar akuntansi } \\
\text { Keuangan, 2018, p. } \\
\text { 112.2) }\end{array}$ & $\begin{array}{l}\text { a. Aset Temporer } \\
\text { Jika nazhir menerima janji (wa'd) untuk berwakaf, maka nazhir tidak } \\
\text { mengakui aset yang akan diwakafkan dimasa mendatang dalam laporan } \\
\text { keuangan. } \\
\text { b. Aset Non-Temporer } \\
\text { Nazhir mengakui aset wakaf dalam laporan keuangan ketika memiliki } \\
\text { kendali secara hukum dan fisik atas aset wakaf tersebut. } \\
\text { c. Jika nazhir menerima wasiat wakaf, maka nazhir tidak mengakui aset yang } \\
\text { akan diwakafkan di masa mendatang dalam laporan keuangan. } \\
\text { d. Jika nazhir menerima janji (wa'd)untuk berwakaf, maka nazhir tidak } \\
\text { mengakui aset yang akan diwakafkan di masa mendatang dalam laporan } \\
\text { keuangan. }\end{array}$ \\
\hline 2 & $\begin{array}{l}\text { Aset Wakaf berupa } \\
\text { Properti Investasi } \\
\text { PSAK No. } 13 \\
\text { Properti Investasi } \\
\text { (IAI D. , Standar } \\
\text { Akuntansi Keuangan, } \\
\text { 2018) }\end{array}$ & $\begin{array}{l}\text { a. Properti investasi diakui sebagai aset jika besar kemungkinan manfaat } \\
\text { ekonomi masa depan yang terkait dengan properti investasi akan mengalir } \\
\text { ke entitas. } \\
\text { b. Biaya perolehan properti investasi dapat diukur secara andal. Tidak ada } \\
\text { biaya harian, melainkan biaya perolehan properti investasi selama } \\
\text { terjadinya ketika mengevaluasi. }\end{array}$ \\
\hline 3 & $\begin{array}{l}\text { Aset Wakaf berupa } \\
\text { Aset tetap } \\
\text { PSAK No.16 tentang } \\
\text { Aset Tetap (IAI D. } \\
\text { Standar Akuntansi } \\
\text { Keuangan, 2018, p. } \\
\text { 16.3) }\end{array}$ & $\begin{array}{l}\text { a. Biaya perolehan aset tetap diakui sebagai aset jika kemungkinan besar } \\
\text { entitas akan memperoleh manfaat ekonomi masa depan dari aset tersebut. } \\
\text { b. Suku cadang, peralatan siap pakai dan peralatan diakui sebagai biaya } \\
\text { perolehan jika tidak maka sebagai persediaan. }\end{array}$ \\
\hline 4 & $\begin{array}{l}\text { Aset Wakaf Tak } \\
\text { Berwujud } \\
\text { PSAK No.19 }\end{array}$ & $\begin{array}{l}\text { a. Aset tak berwujud pada awalnya diakui sebagai biaya perolehan. } \\
\text { b. Pengeluaran atas aset tak berwujud diakui sebagai beban pada saat } \\
\text { terjadinya, kecuali: bagian dari biaya perolehan aset tak berwujud yang }\end{array}$ \\
\hline
\end{tabular}




\begin{tabular}{lll}
\hline & $\begin{array}{l}\text { Aset Tak Berwujud } \\
\text { (IAI D. , Standar } \\
\begin{array}{l}\text { Akuntansi Keuangan, } \\
\text { 2018) }\end{array}\end{array}$ & $\begin{array}{l}\text { memenuhi kriteria pengakuan dan diperoleh melalui suatu kombinasi bisnis } \\
\text { dan tidak dapat diakui sebagai aset tak berwujud. }\end{array}$ \\
\hline $\begin{array}{l}\text { Aset Wakaf berupa } \\
\text { Sukuk }\end{array}$ & a. & $\begin{array}{l}\text { Beban masa lalu tidak boleh diakui sebagai aset } \\
\text { PSAK No.110 }\end{array}$ \\
$\begin{array}{l}\text { Akuntansi Sukuk } \\
\text { (IAI, 2015) }\end{array}$ & $\begin{array}{l}\text { yang terikat dengan ketentuan penerbitan sukuk ijarah. Sukuk ijarah diakui } \\
\text { sebesar nominal, disesuaikan dengan premium atau diskonto dan biaya } \\
\text { transaksi terkait dengan penerbitannya. }\end{array}$ \\
& b. $\begin{array}{l}\text { Bagi akuntansi investor, entitas mengakui investasi pada sukuk ijarah dan } \\
\text { sukuk mudharabah sebesar biaya perolehan. }\end{array}$ \\
\hline
\end{tabular}

\section{Tabel 2. Pengakuan Aset Wakaf}

Pengukuran aset wakaf dapat dilihat dari beberapa PSAK nomor 112, 13, 16, 19 dan 110 yang berkaitan dengan aset wakaf, sebagai berikut:

\begin{tabular}{|c|c|c|}
\hline No & PSAK & Pengukuran \\
\hline 1 & $\begin{array}{l}\text { PSAK No.112 } \\
\text { tentang Akuntansi } \\
\text { Wakaf (IAI D. , } \\
\text { Standar Akuntansi } \\
\text { Keuangan, 2018, p. } \\
\text { 112.5) }\end{array}$ & $\begin{array}{l}\text { a. Pada saat pengakuan awal, aset wakaf diukur sebagai berikut: } \\
\text { 1) Aset wakaf berupa uang diukur pada nilai nominal } \\
\text { 2) Aset wakaf selain uang diukur pada nilai wajar } \\
\text { b. Aset wakaf berupa logam mulia selanjutnya diukur pada nilai wajar dan } \\
\text { perubahannya diakui sebagai dampak pengukuran ulang aset wakaf. }\end{array}$ \\
\hline 2 & $\begin{array}{l}\text { Aset Wakaf berupa } \\
\text { Properti Investasi } \\
\text { PSAK No. } 13 \\
\text { Properti Investasii } \\
\text { (IAI D. , Standar } \\
\text { Akuntansi Keuangan, } \\
\text { 2018) }\end{array}$ & $\begin{array}{l}\text { a. Biaya transaksi termasuk dalam pengukuran awal tersebut. } \\
\text { b. Biaya perolehan awal hak atas properti yang dikuasai dengan cara sewa dan } \\
\text { diklasifikasikan sebagai properti investasi yang dicatat sebagai sewa } \\
\text { pembiayaan diakui pada jumlah yang lebih rendah antara nilai wajar dan } \\
\text { nilai kini pembayaran sewa minimum. }\end{array}$ \\
\hline 3 & $\begin{array}{l}\text { Aset Wakaf berupa } \\
\text { Aset tetap } \\
\text { PSAK No.16 tentang } \\
\text { Aset Tetap (IAI D. , } \\
\text { Standar Akuntansi } \\
\text { Keuangan, 2018, p. } \\
\text { 16.4) }\end{array}$ & $\begin{array}{l}\text { a. Pengukuran saat pengakuan } \\
\text { 1) Aset tetap yang memenuhi kualifikasi pengakuan sebagai aset diukur } \\
\text { pada biaya perolehan setara harga tunai pada tanggal pengakuan. } \\
\text { b. Pengukuran setelah pengakuan } \\
\text { 1) Setelah pengakuan sebagai aset, aset tetap dicatat pada biaya perolehan } \\
\text { dikurangi akumulasi penyusutan dan akumulasi rugi penurunan nilai } \\
\text { atau aset tetap yang nilai wajarnya dapat diukur secara andal dicatat } \\
\text { pada jumlah revaluasian. } \\
\text { 2) Jika jumlah tercatat meningkat, maka diakui dalam penghasilan } \\
\text { komprehensif dan terakumulasi dalam ekuitas pada bagian surplus } \\
\text { revaluasi. } \\
\text { 3) Jika jumlah tercatat turun maka diakui dalam laba rugi. Akan tetapi } \\
\text { diakui dalam penghasilan komprehensif selama tidak melebihi saldo } \\
\text { surplus. } \\
\text { 4) Beban penyusutan diakui dalam laba rugi } \\
\text { 5) Jumlah tersusutkan dari suatu aset dialokasikan secara sistematis sepanjang } \\
\text { umur manfaatnya. }\end{array}$ \\
\hline 4 & $\begin{array}{l}\text { Aset Wakaf Tak } \\
\text { Berwujud } \\
\text { PSAK No.19 } \\
\text { Aset Tak Berwujud } \\
\text { (IAI D. , Standar } \\
\text { Akuntansi Keuangan, } \\
\text { 2018, p. 19.13) }\end{array}$ & $\begin{array}{l}\text { a. Setelah pengakuan awal, aset tak berwujud dicatat pada biaya perolehan } \\
\text { dikurangi akumulasi amortisasi dan akumulasi rugi penurunan nilai } \\
\text { b. Aset tak berwujud tidak direvaluasi karena tidak terdapat pasar aktif, maka } \\
\text { aset tak berwujud dicatat pada harga perolehan dikurangi akumulasi } \\
\text { amortisasi dan akumulasi rugi penurunan nilai } \\
\text { c. Jika tidak lagi dapat diukur dengan referensi pasar aktif maka jumlah } \\
\text { revaluasian pada tanggal terakhir kali revaluasi dilakukan dengan referensi } \\
\text { nilai pasar aktif dikurangi akumulasi amortisasi dan akumulasi rugi } \\
\text { penurunan nilai. } \\
\text { d. Jika jumlah tercatat meningkat maka diakui dalam penghasilan } \\
\text { komprehensif. } \\
\text { e. Jika turun maka penurunan tersebut diakui dalam laba rugi. }\end{array}$ \\
\hline
\end{tabular}


DOI: https://doi.org/10.21009/hayula.004.2.05

\begin{tabular}{ll}
\hline Aset Wakaf berupa & a. Investasi tersebut dimiliki dalam suatu model usaha yang bertujuan utama \\
Sukuk & untuk memperoleh arus kas kontraktual \\
PSAK No.110 & b. $\begin{array}{l}\text { Persyaratan kontraktual menentukan tangga tertentu pembayaran pokok } \\
\text { dan/atau hasilnya. } \\
\begin{array}{l}\text { Akuntansi Sukuk } \\
\text { (IAI, 2015) }\end{array}\end{array}$
\end{tabular}

Tabel 3. Pengukuran Aset Wakaf

\section{Pemulihan Nilai Aset Wakaf Akibat dari Penurunan Nilai Aset di Wakaf Daarut Tauhid}

Wakaf Daarut Tauhid mengelola aset wakaf berupa kendaraan. Kendaraan atau mesin merupakan aset wakaf yang paling cepat mengalami penurunan nilai aset. Berdasarkan PP No.42 Nomor 26 tentang pelaksanaan UU No.41 tahun 2004 tentang wakaf bahwa jenis aset wakaf salah satunya merupakan aset bergerak selain uang seperti kendaraan. Kendaraan merupakan aset yang dapat dimanfaatkan dalam periode jangka panjang, sehingga termasuk ke dalam aset tetap. Menurut PSAK No.48 tentang penurunan nilai aset paragraf 01 bahwa aset yang mengalami penurunan nilai akan dipulihkan, baik dengan cara penjualan atau penggunaan. Selain itu. Dalam PSAK No.16 tentang aset tetap paragraf 43 bahwa aset tetap akan disusutkan. Hal ini berlaku pula dalam aset wakaf, sebagaimana dalam PSAK No.112 tentang akuntansi wakaf dalam DK.22 bahwa aset wakaf yang termasuk depreciable asset akan disusutkan atau diamortisasi, sesuai jenis asetnya. Kebijakan ini berlaku pula pada aset wakaf kendaraan.

Wakaf Daarut Tauhid merupakan salah satu lembaga wakaf yang menerima aset wakaf dalam bentuk kendaraan. Sejauh ini, wakaf DT sudah menerima 2 buah mobil. Pada bulan November 2018, ada seorang keluarga yang mewakafkan mobil Carry tahun 2001 ke Wakaf DT yang digunakan untuk operasional Wakaf DT. Selain itu juga ada orang tua santri di Pesantren DT yang mewakafkan mobil terbaru keluaran 2018 kepada wakaf DT untuk operasional pendidikan. Peruntukkan kendaraan yang diwakafkan sesuai dengan amanah dari wakif dan kendaraan wakaf yang telah ditentukan peruntukkannya menjadi tanggung jawab lembaga yang diberi amanah untuk penggunaannya. Seiring dengan berjalannya waktu, mobil yang termasuk aset tetap pasti akan mengalami penurunan nilai. Menurut staff accounting wakaf DT, “memang mobil wakaf atau kendaraan pasti akan mengalami penurunan nilai". Berdasarkan studi lapangan, wakaf DT belum melakukan penyusutan terhadap aset wakaf, karena pemahaman pengelola wakaf DT menganggap bahwa menurut fikih wakaf nilai harta wakaf tidak berkurang. Artinya wakaf DT memiliki 2 kendaraan dan 
saat ini masih terdapat 2 kendaraan. Harta wakaf yang tidak berkurang dilihat dari jumlah aset wakafnya bukan dari nilai asetnya.

Cara pemulihan aset kendaraan wakaf di wakaf DT pertama tidak memutuskan keputusan sepihak, melainkan meminta fatwa pada Lajnah Syariah (pengawas) bagaimana perlakuan yang tepat terhadap aset kendaraan tersebut. Jika aset itu belum terlalu rusak dan masih bisa dimanfaatkan, maka aset tersebut akan dimanfaatkan terlebih dahulu. Namun jika aset sudah tidak bisa dimanfaatkan dan jika menurut Laj`nah Syariah boleh dijual. Oleh karena itu, untuk menjaga tingkat kemanfaatan aset wakaf perlu dilakukan inventarisasi beserta umur ekonomisnya. Sehingga Lembaga wakaf akan mengetahui sejauh mana kemanfaatan aset wakaf tersebut dapat digunakan. Hal ini, akan mempermudah Lembaga wakaf untuk merencanakan pemulihan aset wakaf dari awal penerimaan aset wakaf bergerak tersebut. Tahapan pemulihan aset wakaf pada Lembaga wakaf sebagai berikut :

1) Melakukan revaluasi atas aset wakaf bergerak seperti kendaraan, mesin dan lainnya

2) Tentukan masa umur ekonomis aset tersebut

3) Tentukan biaya penyusutan per bulannya dengan metode garis lurus atau unit produksi

4) Membuat perencanaan untuk memulihkan aset tersebut dengan cara taghyir al-waqf atau istibdal sehingga pada masa habis umur ekonomis aset wakaf tersebut dapat segera dipulihkan karena perencanaannya sudah jauh hari dilakukan. Hal ini selaras dengan penelitian Karouw yang menyatakan aset wakaf yang mengalami penurunan nilai dan termasuk depreciable assets harus dipulihkan dengan cara dijual atau digunakan (Karouw, 2013).

5) Membuat daftar inventarisasi aset wakaf bergerak yang diterima oleh Lembaga wakaf

6) Proses penyusutan aset wakaf harus diakui, diukur dan disajikan dalam laporan keuangan Lembaga wakaf. Jika tidak, dampak yang akan terjadi adalah aset wakaf lama-kelamaan bisa menghilang karena tidak ada pemulihan.

\section{Penutup}

Berdasarkan hal tersebut maka cara menyikapi kerusakan pada aset wakaf bila dilihat dari fikih wakaf yaitu taghyir al-waqf (Perubahan tatanan alokasi wakaf), dan Istibdlal (Penjualan aset wakaf dan membeli aset baru). Hal tersebut dapat dilakukan untuk mengelola aset wakaf agar terus bermanfaat dan nilainya tidak berkurang. Sedangkan menurut 
akuntansi, pemulihan aset wakaf dapat dijual atau dimanfaatkan. Hal ini mengacu pada PSAK No.112 tentang Akuntansi Wakaf dalam DK.22, PSAK No.16 Tentang Aset tetap pada paragraf 43 dan PSAK No.48 Tentang Penurunan Nilai pada paragraf 01.

Tinjauan fikih dan akuntansi terhadap pemulihan aset wakaf di wakaf Daarut Tauhid belum melakukan proses pencatatan atas penurunan nilai pada aset wakaf kendaraan. Sehingga tidak memiliki metode pemulihan aset baik taghyir al-waqf atau Istibdlal. Oleh karena itu, tahapan dalam memulihkan aset wakaf adalah melakukan revaluasi aset wakaf, menentukan umur ekonomis dan biaya penyusutan serta metode penyusutan yang digunakan. Selanjutnya membuat perencanaan dan daftar inventarisasi aset wakaf untuk menentukan keputusan pemulihan aset wakaf dengan cara taghyir al-waqf atau Istibdlal. Dan melakukan pencatatan sampai penyajian atas penyusutan aset wakaf pada laporan keuangan.

\section{Daftar Pustaka}

Afrizal.Az-Zuhaili, W. (2011). Fiqih Islam wa Adillatuhu (Edisi 10). Jakarta: Gema Insani. Hakim, A. (2019). Hasil Wawancara. Bandung.

Ilyas, M. (2016). Istibdal Harta Benda Wakaf Perspektif Hukum Islam. Jurisprudentie, $3(2), 138-150$.

kementrian Agama. (2006). Fiqh Wakaf. 1-111.

Maftuhah. (2017). ANALISIS HUKUM ISTIBDAL BENDA WAQAF BERUPA MASJID (Studi Komparasi Pendapat Imam al Nawawi dan Ibnu Qudamah).

Rani, M. A. B. M. (2015). Mekanisme Istibdal dalam Pembangunan Tanah Wakaf di Terengganu. Contemporary Islamic Studies, 1, 115-133. https://doi.org/10.13140/RG.2.1.1928.7208

Wakaf daarut Tauhid. (2018). Wakafkan Mobil Kesayangan, Mengapa Tidak? Retrieved November 3, 2018, from instagram wakafdt website: https://www.instagram.com/p/Bptb22aFBPL/

Zaki, E. (2006). A Summary of Waqf Regulations. In A Series Of Translations in Philantropic And Voluntary Work (Vol. 11). Kuwait.

(2016). Metode Penelitian Kualitatif : Sebuah Upaya mendukung penggunaan penelitian kualitatif dalam berbagai disiplin ilmu. Jakarta: PT RajaGrafindo Persada.

Arief, Y., \& Tulab, T. (2018). Model Pengelolaan Tanah Wakaf di Kota Semarang. Jurnal Studi dan Penelitian Hukum Islam, 63-80.

Az-Zuhaili, W. (2011). Figh Islam Wa Adillatuhu. Jakarta: Gema Insani. 
Bayinah, A. N. (2017). Exploring And Empowering Waqf Invesment Toward An Acceleration Of Economic Development In Indonesia. Annual International COnference On Islamic Studies (hal. 2681-2707). Jakarta: Diktis Kemenag.

Bimas Islam. (2013, April 3). Tidak Semua Tanah Wakaf Bisa Ruislah. Diambil kembali dari Kabarwashliyah: http://kabarwashliyah.com/2013/04/03/tidak-semua-tanahwakaf-bisa-ruislah/

Dewan Standar Akuntansi Syariah IAI. (2018). PSAK 112 : Akuntansi Wakaf . Jakarta: Ikatan Akuntan Indonesia.

Fahruroji. (2017). Istibdlal Wakaf : Ketentuan Hukum dan Modelnya. Misykat, (hal. 116).

Fawzi, L. S. (2011, Agustus 20). membuat tanah wakaf menjadi aset produktif melalui konsep strata title. Diambil kembali dari putraproperty.weebly: http://putraproperty.weebly.com/article--property-news/membuat-tanah-wakafmenjadi-aset-produktif-melalui-konsep-strata-title

Firmansyah, A. (2011). Hukum Perubahan Status Wakaf. Jakarta: UIN Syarif Hidayatullah. Diambil kembali dari http://repository.uinjkt.ac.id/dspace/bitstream/123456789/21608/1/AHMAD\%20FI RMANSYAH-FSH.pdf

Hakim, A. (2019, Mei 02). Aset wakaf kendaraan di Wakaf DT. (I. L. Ridwan, Pewawancara)

Hasanah, U. (2009). Laporan Akhir Kajian Hukum Tentang Aspek Hukum Wakaf Uang. Jakarta: Badan Pembinaan Hukum Nasional Departemen Hukum dan Asasi Manusia.

Huda, N., \& Heykal, M. (2015). Lembaga Keuangan Islam : Tinjauan Teoritis dan Praktis. Jakarta: Prenada Media Group.

IAI. (2015, Februari 25). Standar Akuntansi Keuangan. Dipetik Mei 21, 2019, dari IAI Global: http://iaiglobal.or.id/v03/standar-akuntansi-keuangan/Pernyataan-sas-78psak-110-akuntansi

IAI, D. (2018). Standar aAz-Zuhaili, W. (2011). Fiqih Islam wa Adillatuhu (Edisi 10). Jakarta: Gema Insani.

Hakim, A. (2019). Hasil Wawancara. Bandung.

Ilyas, M. (2016). Istibdal Harta Benda Wakaf Perspektif Hukum Islam. Jurisprudentie, $3(2), 138-150$.

Kementrian Agama. (2006). Fiqh Wakaf. 1-111.

Maftuhah. (2017). ANALISIS HUKUM ISTIBDAL BENDA WAQAF BERUPA MASJID (Studi Komparasi Pendapat Imam al Nawawi dan Ibnu Qudamah).

Rani, M. A. B. M. (2015). Mekanisme Istibdal dalam Pembangunan Tanah Wakaf di Terengganu. Contemporary Islamic Studies, 1, 115-133. https://doi.org/10.13140/RG.2.1.1928.7208

wakaf daarut Tauhid. (2018). Wakafkan Mobil Kesayangan, Mengapa Tidak? Retrieved 
November 3, 2018, from instagram wakafdt website: https://www.instagram.com/p/Bptb22aFBPL/

Zaki, E. (2006). A Summary of Waqf Regulations. In A Series Of Translations in Philantropic And Voluntary Work (Vol. 11). Kuwait.

IAI, D. (2018). Standar Akuntansi Keuangan. Dalam PSAK No.13 tentang Properti Investasi (hal. 13.4). Jakarta: DSAK IAI.

IAI, D. (2018). Standar Akuntansi Keuangan. Dalam PSAK No. 16 Tentang Aset Tetap (hal. 16.2). Jakarta: DSAK IAI.

IAI, D. (2018). Standar Akuntansi Keuangan. Dalam PSAK No.19 Tentang Aset Tak Berwujud (hal. 19.5). Jakarta: DSAK IAI.

IAI, D. (2018). Standar Akuntansi Keuangan. Dalam PSAK No.112 tentang Akuntansi Wakaf (hal. 112.7). Jakarta: DSAK IAI.

IAI, D. (2018). Standar Akuntansi Keuangan. Dalam PSAK No. 48 tentang Penurunan Nilai Aset (hal. 48.3). Jakarta : DSAK IAI.

IAI, D. (2018). Standar Akuntansi Keuangan. Dalam PSAK No.48 Tentang Penurunan Nilai (hal. 48.4). Jakarta: DSAK IAI.

Ihsan, H. (2017). Diambil kembali dari http://repository.umy.ac.id/bitstream/handle/123456789/19926/BAB\%20IV.pdf?se quence $=8 \&$ is Allowed $=\mathrm{y}$

Ikatan Akuntan Indonesia. (2009, Oktober). PSAK 48 Tentang Penurunan Nilai Aset. Jakarta. Diambil kembali dari http://iaiglobal.or.id/v03/standar-akuntansikeuangan/pernyataan-sak-34-psak-48-penurunan-nilai-aset

Ikatan Akuntan Indonesia. (2015, November). PSAK 16 Tentang Aset Tetap. Jakarta: IAI. Diambil kembali dari http://tempdata.iaiglobal.or.id/files/ED\%20Amandemen\%20PSAK\%2016\%20(07 $\% 20$ Sept15).pdf

Institute Agama Islam Ciamis. (2018, Oktober 9). Pengelolaan Wakaf Uang Di Indonesia. Diambil kembali dari IAID Ciamis Jawa Barat: https://www.iaid.ac.id/post/read/359/pengelolaan-wakaf-uang-di-indonesia.html

Karouw, H. F. (2013). Analisis Penerapan PSK NO.48 (Revisi 2009) Penurunan Nilai Aset Tetap pada Rumah Sakit Umum Ousat Prof. Dr.R.D. Kandou Manado. EMBA, (hal. 2040).

Kasdi, A. (2014). Potensi Ekonomi Dalam Pengelolaan Wakaf Uang Di Indonesia. Equilibrium, 2 No 1.

M.Habibi. (2017). Fiqh Waqaf. Kediri: Santri Salaf Press.

Misno, A., \& Rifai, A. (2018). Metode Penelitian Muamalah. Jakarta: Salemba Diniyah.

Nasar, F. (2018, Maret 25). Kemenag Dorong Percepatan Sertifikasi Tanah Wakaf. Diambil kembali dari nusakini.com: http://nusakini.com/news/kemenag-dorongpercepatan-sertifikasi-tanah-wakaf 
Nasar, F. (2018, February 12). Nazhir Wajib Pahami Hukum Wakaf. Diambil kembali dari Bimas Islam : Direktorat Jenderal Bimbingan Msayarakat Islam: https://bimasislam.kemenag.go.id/post/berita/nazhir-wajib-pahami-hukum-wakaf

Presiden Republik Indonesia. (2004, Oktober 27). Undang-Undang Republik Indonesia Nomor 41 Tahun 2004 Tentang Wakaf. Jakarta, DKI Jakarta, Indonesia: Menteri Sekretaris Negara Republik Indonesia.

Ridwan, D. M. (2019, April 18). Penurunan Nilai pada Mobil. (I. L. Ridwan, Pewawancara)

Santoso, N. H. (2017). ANALISIS PENGELOLAAN DAN PELAPORAN KEUANGAN WAKAF TUNAI PADA TABUNG WAKAF INDONESIA. Surakarta: INSTITUT AGAMA ISLAM NEGERI SURAKARTA.

Saptono, I. T. (2019, Agustus 8). Dipandang Perlu Peraturan Mitigasi Risiko Wakaf Saham . Diambil kembali dari Pasar Dana: https://pasardana.id/news/2019/8/8/dipandang-perlu-peraturan-mitigasi-risikowakaf-saham/

Senjiati, I. H., \& Sulistiani, S. L. (2019). Manajemen dan Akuntansi Wakaf. Dalam D. M. dkk, Akuntansi Wakaf (hal. 94-95). Jakarta: Erlangga.

Siddiq, A. (2013). PRAKTIK MASSLAHAT AL-ISTIBDĀL WAKAF. Semarang: Program Doktor IAIN Walisongo Semarang. Diambil kembali dari http://eprints.walisongo.ac.id/22/2/ACHMAD_SIDDIQ_DISERTASI_SINOPSIS.p df

SINDO. (2018, Oktober 1). Wakaf Melalui Uang Cegah Penyusutan Lahan Pertanian. Diambil kembali dari Sindo Weekly: http://www.sindoweekly.com/analysis/magz/no-31-tahun-vii/wakaf-melalui-uangcegah-penyusutan-lahan-pertanian

Sulistiani, S. L. (2017). Pembaruan Hukum Wakaf di Indonesia. Bandung: Refika Aditama.

Suryowati, E. (2019, Agustus 8). Wakaf Saham, Investasi Dunia-Akhirat Kolaborasi Global Wakaf-ACT dan BNI Sekuritas. Diambil kembali dari JawaPos.com: https://www.jawapos.com/ekonomi/finance/08/08/2019/wakaf-saham-investasidunia-akhirat/

Tarsifah, H. (2017). Manajemen Wakaf Produktif. Semarang: UIN Walisongo .

W.Crewsell, J. (2016). Research Design. (A. Fawaid, \& R. K. Pancasari, Penerj.) Yogyakarta: Pustaka Pelajar.

Waqafdt. (2018, November 28). Wakafkan mobil kesayangan. Dipetik April 22, 2019, dari www.instagram.com: https://www.instagram.com/p/B[tb22aFBPL

Yaacob, H., \& Nahar, H. S. (2017). Investigating Awqaf Management, Accounting and Investment Practices in Malaysia: The Case of a State Religious Institution. GJAT, 59-70. 